\title{
Stability-indicating RP-HPLC method for simultaneous estimation of levosalbutamol sulfate and theophylline in combined dosage form
}

\author{
Sagar Suman Panda*, Bera VenkataVaraha Ravi Kumar, Ganeswar Mohanta
}

Department of Pharmaceutical Analysis and Quality Assurance, Roland Institute of Pharmaceutical Sciences, Odisha, India

\begin{abstract}
A novel, simple, accurate and precise RP-HPLC method for simultaneous determination of levosalbutamol sulfate and theophylline has been developed and validated. Separation was achieved on a Phenomenex; $\mathrm{C}_{18}$ column $(250 \mathrm{~mm} \times 4.6 \mathrm{~mm}$ i.d., $5 \mu \mathrm{m})$ using methanol: $10 \mathrm{mM}$ TBAHS(tetrabutyl ammonium hydrogen sulfate) $(50: 50, \mathrm{v} / \mathrm{v})$ as mobile phase at flow rate of $1.0 \mathrm{~mL} \cdot \mathrm{min}^{-1}$. The UV detection wavelength was $274 \mathrm{~nm}$. The linearity is obeyed over a concentration range of $0.5-150 \mu \mathrm{g} . \mathrm{mL}^{-1}$ with correlation coefficient of 0.999 for both the drugs. The proposed method was validated by determining accuracy, precision, stability and system suitability parameters. The method was found to be robust. Specificity of the method was determined by subjecting the drugs to various stress conditions like acid, alkali, oxidation, thermal and photolytic degradation. The method was used successfully for the simultaneous determination of levosalbutamol sulfate and theophylline in syrup dosage form.
\end{abstract}

Uniterms: Levosalbutamol/determination. Theophylline/determination. Stability-indicating. RP-High performance liquid chromatography/qualitative analysis Syrup/qualitative analysis.

\begin{abstract}
Desenvolveu-se e validou-se método de RP-HPLC novo, simples, exato e preciso de determinação simultânea do sulfato de levossalbutamol e teofilina.. A separação foi efetuada em uma coluna Phenomenex; C18 (250 mm x 4,6 mm d.i., $5 \mu \mathrm{m}$ ) utilizando metanol: TBAHS (hidrogenossulfato de tetrabutilamônio) $10 \mathrm{mM}$ (50:50, v/v) como fase móvel, com fluxo de 1,0 mL.min ${ }^{-1}$. O comprimento de onda de detecção no UV foi $274 \mathrm{~nm}$. Observou-se linearidade na faixa de concentração de $0,5-150 \mu \mathrm{g} \mathrm{mL}^{-1}$, com coeficiente de correlação de 0,999 para ambos os fármacos. O método proposto foi validado determinando-se exatidão, precisão, estabilidade e parâmetros de adequação do sistema. $\mathrm{O}$ método mostrou-se robusto. A especificidade do método foi determinada submetendo os fármacos a várias condições de estresse, como ácido, álcali, oxidação, degradação térmica e fotolítica. O método foi usado com sucesso para a determinação simultânea do sulfato de levossalbutamol e teofilina na forma de xarope.
\end{abstract}

Unitermos: Levosalbutamol/determinação. Teofilina/determinação. Indicador de estabilidade. RP-Cromatografia líquida de alto desempenho. Xarope/análise qualitativa

\section{INTRODUCTION}

Levosalbutamol sulfate (levalbuterol), $(R)-\alpha^{\prime}-[($ tert butylamino)-4-hydroxy- $m$-xylene- $\alpha \alpha^{\prime}$-diol sulfate $(2: 1)$ is a bronchodilator indicated for management of asthma. It is preferred over racemic salbutamol sulfate for increased efficacy and safety after use (Berger, 2003). Theophylline, 3,7-dihydro-1,3-dimethyl purine-2,6(1H)-dione is a xanthine derivative used for management of asthma and

*Correspondence: S. S. Panda. Department of Pharmaceutical Analysis and Quality Assurance, Roland Institute of Pharmaceutical Sciences, Ambapua, Berhampur, 760010 - Odisha, India. E-mail: sagarguddu2002@gmail.com related obstructive respiratory conditions(Persson,1986). The chemical structure of both the drugs are shown in Figure 1.

Literature review shows that no stability-indicating RP-HPLC methods are present so far for simultaneous estimation of levosalbutamol sulfate and theophylline in combined syrup dosage form using methanol: $10 \mathrm{mM}$ TBAHS (tetra butyl ammonium hydrogen sulfate) as the mobile phase. Some of the reported methods for racemic salbutamol sulfate includes titrimetric (Basavaiah et al., 2006, 2007), potentiometric (Abdel-Ghani et al., 2002), spectrophotometric (Basavaiah et al., 2003, 2006, 2007; Chitlange et al., 2011; Culzoni et al., 2006; Geeta et 


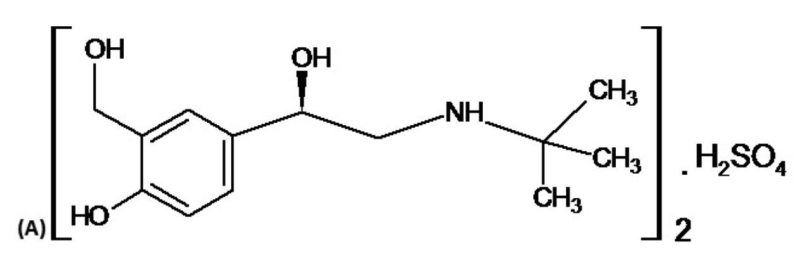<smiles>Cn1c(=O)c2[nH]cnc2n(C)c1=O</smiles>

FIGURE 1 - Chemical Structure of (A) levosalbutamol sulfate and (B) theophylline.

al., 1989; Habib et al., 2004; Jain et al., 2011; Mishra et al., 2010; Parimoo et al., 1993; Rathore et al., 1993), spectrofluorimetric (Pandya et al., 2010), HPLC (Bernal et al., 1996; Boulton et al., 1995; Chitlange et al., 2011; Erram et al., 2006; Jain et al., 2011; Kasawar et al., 2010; Kountourellis et al., 1990; Martis et al., 2011; Murtaza et al., 2009; Pai et al., 2009) and LC-MS(Joyce et al., 1998; Wu et al., 2004, 2011; Yee et al., 2011). Whereas for levosalbutamol sulfate a few spectrophotometric (Prasanna et al., 2012; Thulasama et al., 2009) and HPLC (Ghemud et al., 2012; Halabi et al., 2004; Prasanna et al., 2012) methods are reported. The reported methods for theophylline includes spectrophotometric (Abuirjeie et al., 1992; Bermejo et al., 1985; Carter et al., 1985; Fellenberg et al., 1979; Hohnadel et al., 1978; Jatlow, 1975; Kumar et al., 2011; Plavsic, 1978; Vasiliades et al., 1976), HPLC (Abuirjeie et al., 1992; Boberic-Borojevic et al., 1999; Greenberg et al., 1979; Lauff, 1987; Moncrieff, 1991; Papadoyannis et al., 1993; Shidhaye et al., 2009), GC (Chrzanowski et al., 1974; Schwertner, 1979; Shah et al., 1974) and LC-MS (Abdel-Hamid et al., 2003; Babu et al., 2011; Kanazawa et al., 2000; Song et al., 2004). The literature survey suggests there is lack of a stability indicating RP-HPLC method for simultaneous determination of levosalbutamol sulfate and theophylline in combined syrup dosage forms. Only one RP-HPLC method has been reported so far for simultaneous estimation of the racemic salbutamol sulfate and theophylline in combined tablet dosage form (Maithani et al., 2011). But the reported method has several drawbacks like maintaining $\mathrm{pH}$ of buffer, increased retention times of the drugs, narrow range of linearity and higher mobile phase flow rate etc. So, an attempt was made to overcome these drawbacks and develop a novel, simple, accurate and precise, stability-indicating RP-HPLC method for simultaneous determination of levosalbutamol sulfate and theophylline in syrup dosage form. To prove the stabilityindicating nature of the method forced degradation of drug substances and drug product was performed under stress conditions (acid, alkali, oxidation, thermal and photolysis), and the stressed samples were analyzed by the developed method. The method was also validated according to requirements of ICH (International Conference on Harmonization of Technical Requirements for Registration of Pharmaceuticals for Human Use, 2005) guideline.

\section{MATERIAL AND METHODS}

\section{Material}

Methanol used was of HPLC grade (Merck Ltd., Mumbai, India). Water for chromatography was obtained using TKA water purification system (Germany). Standard drug of levosalbutamol sulfate (purity $>99.5 \%$ ) and theophylline (purity $>99 \%$ ) were received from Cipla Ltd., India and Glenmark Pharmaceuticals Ltd., India, respectively. AR grade Tetra Butyl Ammonium Hydrogen Sulfate (TBAHS) was procured from HiMedia Laboratories Pvt. Ltd., India. Marketed syrup formulation was bought from the local market.

\section{Chromatographic conditions}

Quantitative HPLC was performed on a binary gradient HPLC with Shimadzu LC-10AT and LC-10AT VP Series HPLC pumps, with a $20 \mu \mathrm{L}$ sample injection loop (manual) and SPD 10A VP series UV-Visible detector. The signal was monitored and integrated using Shimadzu ClassVP Version 6.12 SP1 Software. A Phenomenex; $\mathrm{C}_{18}$ column $(250 \mathrm{~mm} \times 4.6 \mathrm{~mm}$ i.d., $5 \mu \mathrm{m})$ was used for separation. Methanol: $10 \mathrm{mM}$ TBAHS in the ratio $(50: 50, \mathrm{v} / \mathrm{v})$ was used as the mobile phase. The $10 \mathrm{mM}$ TBAHS solution was prepared by accurately weighing $3.3954 \mathrm{~g}$ of TBAHS salt and dissolving it in $1000 \mathrm{~mL}$ of HPLC grade water. Afterwards, both the methanol and TBAHS solution were ultrasonicated up to $30 \mathrm{~min}$ for degassing and were filtered through a $0.45 \mu \mathrm{m}$ membrane filter, prior to use. The flow rate was $1.0 \mathrm{~mL} \cdot \mathrm{min}^{-1}$ and UV detection was carried out at $274 \mathrm{~nm}$. The separation was achieved at room temperature.

\section{Preparation of standard stock solution}

Standard stock solutions for both the drugs were prepared separately by dissolving $25 \mathrm{mg}$ of drugs in mobile phase up to $25 \mathrm{~mL}$. The volumetric flasks having 
$10 \mathrm{~mL}$ of mobile phase with the drugs were shaken and finally volume was made up to get a concentration of $1000 \mu \mathrm{g} . \mathrm{mL}^{-1}$. Both the standard drug solutions were filtered through a $0.2 \mu \mathrm{m}$ membrane filter. The stock solutions were stored at $2-8{ }^{\circ} \mathrm{C}$.

\section{Method validation}

\section{Linearity and preparation of analytical curve}

Suitable aliquots of the standard stock solutions of levosalbutamol sulfate $\left(1000 \mu \mathrm{g} . \mathrm{mL}^{-1}\right)$ and theophylline $\left(1000 \mu \mathrm{g} . \mathrm{mL}^{-1}\right)$ were transferred into a series of $10 \mathrm{~mL}$ volumetric flasks to get final concentrations of $0.5,1.0,5.0$, $10,20,40,80,100_{2} 150 \mu \mathrm{g} \cdot \mathrm{mL}^{-1}$ (9 points). Final volume was made up with mobile phase. Each mixed standard solution was injected and chromatograms were recorded. The linearity of analytical curves was plotted for peak area of each drug against concentrations of drug.

\section{Analysis of syrup dosage form}

Five $\mathrm{mL}$ of the syrup containing levosalbutamol sulfate and theophylline equivalent to $5 \mathrm{mg}$ and $50 \mathrm{mg}$ of the standard drugs respectively was measured accurately and dissolved in $50 \mathrm{~mL}$ of mobile phase. It was ultrasonicated for 25 minutes and volume was made up with the mobile phase, followed by filtration through $0.2 \mu \mathrm{m}$ membrane filter. The syrup solution was further diluted with the mobile phase to get sample solutions within the linearity range. The sample solutions were injected and chromatograms were obtained. The amount of drug present in the sample solution was calculated using the analytical curves of standard drugs.

\section{Precision}

The precision (intraday and interday) of the method was ascertained from the peak areas obtained by determination of six replicates of fixed amount of drugs. The system precision was ascertained by carrying out six injections of a fixed amount of drug solution. The percent relative standard deviations were calculated.

\section{Accuracy}

To check the accuracy of the proposed method, recovery studies were carried out at 80,100 and $120 \%$ of the test concentration according to ICH guidelines. The recovery study was performed three times at each level.

\section{Robustness}

Robustness of the method was studied by deliberately changing the UV detection wavelength $( \pm 5 \mathrm{~nm})$, mobile phase flow rate $( \pm 0.2 \mathrm{~mL})$ and organic phase composition
$( \pm 5 \%)$.The effect was studied in terms of various system suitability parameters like retention time, resolution, theoretical plates and tailing factor for both the drugs. Solution stability study was also carried out by keeping the sample solutions at $25 \pm 2{ }^{\circ} \mathrm{C}$ for $24 \mathrm{~h}$.

\section{Forced degradation study}

Specificity of the method was determined by checking interference of any of the possible degradation products produced during the forced degradation study. The forced degradation was carried out with $0.1 \mathrm{M} \mathrm{HCl}$, $0.1 \mathrm{M} \mathrm{NaOH}, 3 \% \mathrm{v} / \mathrm{v}$ hydrogen peroxide, thermal $\left(80^{\circ} \mathrm{C}\right)$ and photolysis $(365 \mathrm{~nm})$ for finding out the stability nature of the drugs. The degradation samples were prepared by taking suitable aliquots of the drug and drug product solutions, and then undertaking the respective stress testing procedures for each solution. After the fixed time period the treated drug solutions were diluted with mobile phase. For every stress condition three solutions were prepared as $1 \mu \mathrm{g} \cdot \mathrm{mL}^{-1}$ of levosalbutamol sulfate, $10 \mu \mathrm{g} . \mathrm{mL}^{-1}$ of theophylline and drug product solution containing $1 \mu \mathrm{g} \cdot \mathrm{mL}^{-1}$ of levosalbutamol sulfate with $10 \mu \mathrm{g} \cdot \mathrm{mL}^{-1}$ of theophylline. The specific stress conditions are described as follows.

\section{A) Acidic degradation}

Acidic degradation was carried out by adding $1.0 \mathrm{~mL}$ of $0.1 \mathrm{M} \mathrm{HCl}$, and after $1 \mathrm{hr}$ neutralizing the mixture by adding $0.1 \mathrm{M} \mathrm{NaOH}$.

B) Alkali degradation

Alkali degradation was carried out by adding $1.0 \mathrm{~mL}$ of $0.1 \mathrm{M} \mathrm{NaOH}$, and after $1 \mathrm{~h}$ neutralizing the mixture by adding $0.1 \mathrm{M} \mathrm{HCl}$.

C) Oxidative degradation

Oxidative degradation was performed by exposing the drug to $1.0 \mathrm{~mL}$ of $3 \%(\mathrm{v} / \mathrm{v}) \mathrm{H}_{2} \mathrm{O}_{2} 1 \mathrm{~h}$.

D) Thermal degradation

Thermal degradation was performed by heating the drug solutions at $80^{\circ} \mathrm{C}$ on a thermostatically controlled water bath for $1 \mathrm{~h}$.

E) Photolytic degradation condition

Photolytic degradation was carried out by exposing the drug solutions to UV light $(365 \mathrm{~nm})$ inside an UV chamber for $5 \mathrm{~h}$.

\section{System suitability}

The System Suitability was calculated for different parameters like theoretical plates, resolution, tailing factor, LOD and LOQ. The LOD and LOQ were separately determined based on the Signal to Noise ratio. For LOD the $\mathrm{S} / \mathrm{N}$ ratio is $3: 1$. For LOQ the $\mathrm{S} / \mathrm{N}$ ratio is $10: 1$. 


\section{RESULTS AND DISCUSSION}

\section{Method development and optimization}

Method development process was carried out by examining conditions like flow rate $\left(0.8 \mathrm{~mL} \cdot \mathrm{min}^{-1}\right.$, $1.0 \mathrm{~mL} \cdot \mathrm{min}^{-1}$ and $1.2 \mathrm{~mL} \cdot \mathrm{min}^{-1}$ ), mobile phase compositions like acetonitrile:water, acetonitrile:buffer, methanol:water, methanol: $10 \mathrm{mM}$ TBAHS and ratios (50:50, 60:40 and $45: 60, \mathrm{v} / \mathrm{v}$ ) were used. Both the drugs levosalbutamol sulfate and theophylline were found showing a significant UV absorbance at $274 \mathrm{~nm}$ in methanol: $10 \mathrm{mM}$ TBAHS $(50: 50, \mathrm{v} / \mathrm{v})$, so this wavelength was chosen for UV detection. By use of a $\mathrm{C}_{18}$ column it was found the mobile phase consisting of methanol: 10mM TBAHS $(50: 50, \mathrm{v} / \mathrm{v})$ provided well defined peak shape with good resolution. Levosalbutamol sulfate was eluted at $2.558 \mathrm{~min}$ where as theophylline eluted at $4.867 \mathrm{~min}$. The representative chromatograms of pure drug and combined drug product are shown in Figure 2 (A) and (B), respectively.

\section{Method validation}

Linearity

Levosalbutamol sulfate and theophylline have linearity over concentrations ranging from 0.5 to $150.0 \mu \mathrm{g} \cdot \mathrm{mL}^{-1}$. The slope (a) and intercept (b) were found to be 6103 and 4583 for levosalbutamol sulfate and 63827 and -2793 for theophylline. Correlation coefficient $\left(\mathrm{r}^{2}\right)$ was found to be 0.999 for both the drugs. These results suggest a good linear relationship between peak area and analytes in the range studied.

\section{Analysis of syrup dosage forms}

The $\%$ recovery was more than $100 \%$ for syrup dosage form. Good \% recovery and noninterference in separation of both the drugs because of formulation components suggests that; the method is selective and excipients present in the formulation have no affect in the determination. The results are given in Table I.

\section{Precision}

The RSD for method (intraday and interday) and system precision were found to be less than $2 \%$ showing high degree of preciseness as shown in Table II.

\section{Accuracy}

Accuracy was checked by preparing mixtures containing different amounts of pure drugs and fixed amount of formulation; analyzing the mixtures by use
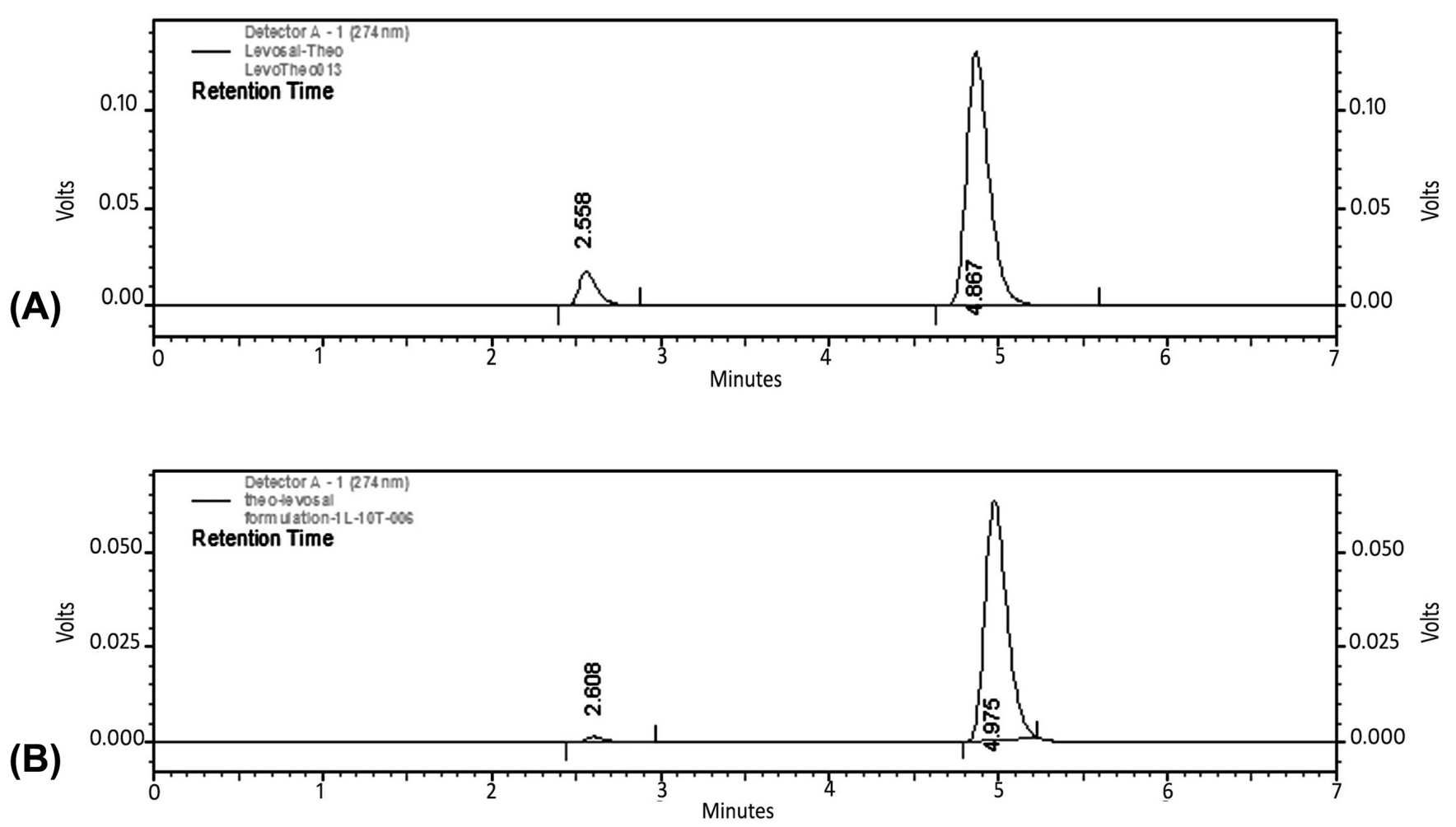

FIGURE 2 - Representative chromatograms of levosalbutamol sulfate and theophylline. (A) combined standard drugs[ratio 1:1] (B) combined formulation[ratio 1:10]. 
TABLE I - Analysis of syrup dosage form

\begin{tabular}{|c|c|c|c|}
\hline \multirow{2}{*}{$\begin{array}{l}\text { Formulation } \\
\text { Type }\end{array}$} & \multirow{2}{*}{ Labeled Amount (mg) } & \multicolumn{2}{|c|}{$\begin{array}{c}\text { Recovery by proposed method }(\%) \pm \text { S.D., } \\
\text { R.S.D }(\%)\end{array}$} \\
\hline & & Levosalbutamol sulfate & Theophylline \\
\hline Syrup & $\begin{array}{c}\text { Each } 5 \mathrm{~mL} \text { contains } \\
\text { levosalbutamol sulfate } \approx 5 \mathrm{mg} \\
\text { theophylline } \approx 50 \mathrm{mg}\end{array}$ & $\begin{array}{c}101.6 \pm 1.4106 \\
1.38\end{array}$ & $\begin{array}{c}101.43 \pm 0.9237 \\
0.91\end{array}$ \\
\hline
\end{tabular}

${ }^{a}$ average of three determinations

TABLE II - Intraday, interday and system precision studies $(\mathrm{n}=6)$

\begin{tabular}{|c|c|c|c|c|}
\hline \multirow{2}{*}{ Type of Study } & \multicolumn{2}{|c|}{ Concentration Taken $\left(\mu \mathrm{g} \cdot \mathrm{mL}^{-1}\right)$} & \multicolumn{2}{|c|}{ Peak Area \pm Standard Deviation, $(\%$ RSD $)$} \\
\hline & Levosalbutamol Sulfate & Theophylline & Levosalbutamol sulfate & Theophylline \\
\hline Intraday precision & 20 & 20 & $\begin{array}{l}125306.83 \pm \\
260.13,0.21\end{array}$ & $\begin{array}{c}1246288 \pm \\
4391.99,0.35\end{array}$ \\
\hline Interday precision & 20 & 20 & $\begin{array}{c}126566 \pm \\
356.59,0.28\end{array}$ & $\begin{array}{c}1246723 \pm \\
3592.9,0.29 \\
\end{array}$ \\
\hline System precision & 20 & 20 & $\begin{array}{l}126234.16 \pm \\
366.88,0.29\end{array}$ & $\begin{array}{c}1264023 \pm \\
3545.68,0.28\end{array}$ \\
\hline
\end{tabular}

${ }^{\mathrm{b}}$ average of six determinations

of developed method. Percentage recovery and relative standard deviation were also calculated. The results obtained suggest the recoveries were excellent, and relative standard deviations were less than $2 \%$.The results of recovery study are given in Table III.

\section{Robustness}

The method was found to be robust under deliberate changes made in mobile phase flow rate, composition of organic phase and UV detection wavelength. Various system suitability parameters were evaluated to find out the robustness of the method. The results for system suitability parameters are presented in Table IV. The results of solution stability for both the drugs was satisfactory with a recovery more than $99 \%$ after $24 \mathrm{~h}$, showing no significant loss of the analytes in the selected mobile phase.

\section{Specificity}

Specificity of the method was ascertained by checking any interference because of excipients or degradation products produced after subjecting levosalbutamol sulfate and theophylline to forced degradation. No extra peaks were obtained either from the excipients used in the drug product or from the stress conditions applied on the drugs and drug product. Therefore the method was found specific and stability-indicating. Forced degradation conditions were optimized in order to get degradation of the drugs up to $30 \%$. The stress conditions like $0.1 \mathrm{M} \mathrm{HCl}, 0.1 \mathrm{M}$ $\mathrm{NaOH}, 3 \% \mathrm{v} / \mathrm{v} \mathrm{H}_{2} \mathrm{O}_{2}, 80{ }^{\circ} \mathrm{C}$ temperature and $365 \mathrm{~nm} \mathrm{UV}$ radiation were applied to check the degradation nature of the drugs. Levosalbutamol sulfate undergoes significant degradation (34.15\%) in oxidative stress, moderate degradation in alkaline (5.64\%) and thermal (3.67\%)

TABLE III - Accuracy of the method

\begin{tabular}{lcccc}
\hline $\begin{array}{l}\text { Different concentration } \\
\text { level comparing to sample } \\
\text { concentration (\%) }\end{array}$ & \multicolumn{2}{c}{$\begin{array}{c}\text { Amount Added } \\
\text { Pure Drug } \\
\left(\mu \mathrm{g} . \mathrm{mL}^{-1}\right)\end{array}$} & \multicolumn{2}{c}{$\begin{array}{c}\text { Recoveryc }(\%) \\
\text { Pure Drug } \\
\pm \text { SD, RSD (\%) }\end{array}$} \\
\cline { 2 - 5 } & Levosalbutamol Sulfate & Theophylline & Levosalbutamol Sulfate & Theophylline \\
\hline 80 & 4 & 40 & $100.5 \pm 0.4330,0.43$ & $101.11 \pm 0.5478,0.54$ \\
100 & 5 & 50 & $100.43 \pm 0.1571,0.16$ & $100.61 \pm 0.2402,0.24$ \\
120 & 6 & 60 & $100.33 \pm 0.33,0.33$ & $100.81 \pm 0.4463,0.44$ \\
\hline
\end{tabular}

${ }^{c}$ average of three determinations at each level 
TABLE IV- Robustness of the method

\begin{tabular}{|c|c|c|c|c|c|c|c|}
\hline \multirow[b]{2}{*}{ Parameter } & \multicolumn{2}{|c|}{ RetentionTime(Rt),min } & \multirow{2}{*}{$\begin{array}{l}\text { Resolution } \\
\text { (Rs) }\end{array}$} & \multicolumn{2}{|c|}{ Theoretical Plates $(\mathrm{N})$} & \multicolumn{2}{|c|}{ Tailing Factor(T) } \\
\hline & $\begin{array}{c}\text { Levosalbutamol } \\
\text { sulfate }\end{array}$ & Theophylline & & $\begin{array}{l}\text { Levosalbutamol } \\
\text { sulfate }\end{array}$ & Theophylline & $\begin{array}{l}\text { Levosalbutamol } \\
\text { sulfate }\end{array}$ & Theophylline \\
\hline \multicolumn{8}{|l|}{$\begin{array}{l}\text { Flow rate } \\
\left(\mathrm{mL} \cdot \mathrm{min}^{-1}\right)\end{array}$} \\
\hline 0.8 & 3.167 & 6.042 & 5.75 & 2938 & 5945 & 1.39 & 1.33 \\
\hline 1.0 & 2.575 & 4.967 & 5.98 & 2926 & 5989 & 1.36 & 1.33 \\
\hline 1.2 & 2.142 & 4.083 & 5.54 & 2838 & 5427 & 1.36 & 1.33 \\
\hline \multicolumn{8}{|l|}{$\begin{array}{c}\text { Methanol } \\
(\%)\end{array}$} \\
\hline 45 & 2.592 & 5.433 & 6.31 & 2899 & 5685 & 1.31 & 1.39 \\
\hline 50 & 2.575 & 4.967 & 5.98 & 2926 & 5989 & 1.36 & 1.33 \\
\hline 55 & 2.533 & 4.483 & 5.57 & 2992 & 5673 & 1.31 & 1.36 \\
\hline \multicolumn{8}{|l|}{$\begin{array}{l}\text { Wavelength } \\
\quad(\mathrm{nm})\end{array}$} \\
\hline 269 & 2.575 & 4.975 & 6.0 & 2941 & 5900 & 1.31 & 1.34 \\
\hline 274 & 2.575 & 4.967 & 5.98 & 2969 & 5989 & 1.36 & 1.33 \\
\hline 279 & 2.558 & 4.875 & 5.79 & 2895 & 5695 & 1.34 & 1.37 \\
\hline
\end{tabular}

stress conditions. Levosalbutamol was found to be stable in the applied acidic and UV stress conditions. The drug theophylline was found to be more stable towards the applied stress conditions than compared to levosalbutamol. Theophylline undergoes moderate degradation in alkaline $(7.57 \%)$ and oxidative $(2.47 \%)$ stress conditions, and the drug was found to be stable in the applied acidic, thermal and UV stress conditions. Figure 3-(A), (B), (C), (D), (E) and (F) represents the chromatograms of untreated drugs; acid, alkali, oxidation, thermal and photolysis degraded drugs with combined drug product, respectively.

\section{System suitability}

A critical evaluation of the method was performed. A higher resolution value indicates better separation of both the drugs. Also the LOD and LOQ values show superior sensitivity of the method. The System suitability parameters are shown in Table V.

\section{CONCLUSION}

This simple and accurate RP-HPLC method has been developed and validated for determining levosalbutamol sulfate and theophylline in syrup dosage form. Lack of a stability-indicating method for determination of both the drugs in a combined syrup dosage form is the driving cause for development of this novel method. The sample preparation technique is also very simple for the syrup dosage form making it suitable for routine laboratory
TABLE V- System suitability

\begin{tabular}{lcc}
\hline \multirow{2}{*}{ Parameter } & \multicolumn{2}{c}{ Obtained Values } \\
\cline { 2 - 3 } & $\begin{array}{c}\text { Levosalbutamol } \\
\text { sulfate }\end{array}$ & Theophylline \\
\hline Retention time & 2.558 & 4.867 \\
Theoretical plates & 2926 & 5989 \\
Tailing factor & 1.36 & 1.33 \\
Resolution & --- & 5.94 \\
LOD $\left(\mu \mathrm{g} \cdot \mathrm{mL}^{-1}\right)$ & 0.16 & 0.015 \\
LOQ $\left(\mu \mathrm{g} \cdot \mathrm{mL}^{-1}\right)$ & 0.54 & 0.051 \\
\hline
\end{tabular}

testing. Major advantage of this method is the analytes do not interfere with each other's elution with a good difference in retention times. Specificity study carried out by forced degradation ensures that the method is specific and able to describe the stability nature of both the drugs in a combined drug formulation. The mobile phase is simple to prepare. Results of precision study demonstrate the superior preciseness of the method as the RSD values were well within the limits. The recovery value of more than $100 \%$ shows higher levels accuracy of the method. So it can be concluded that the developed RP-HPLC method is novel, simple, accurate, precise, sensitive, and stability-indicating and can be employed successfully for the simultaneous determination of levosalbutamol sulfate and theophylline in syrup dosage form. Further the developed method may be applied for bioavailability and bioequivalence study of both the drugs in different biological samples. 


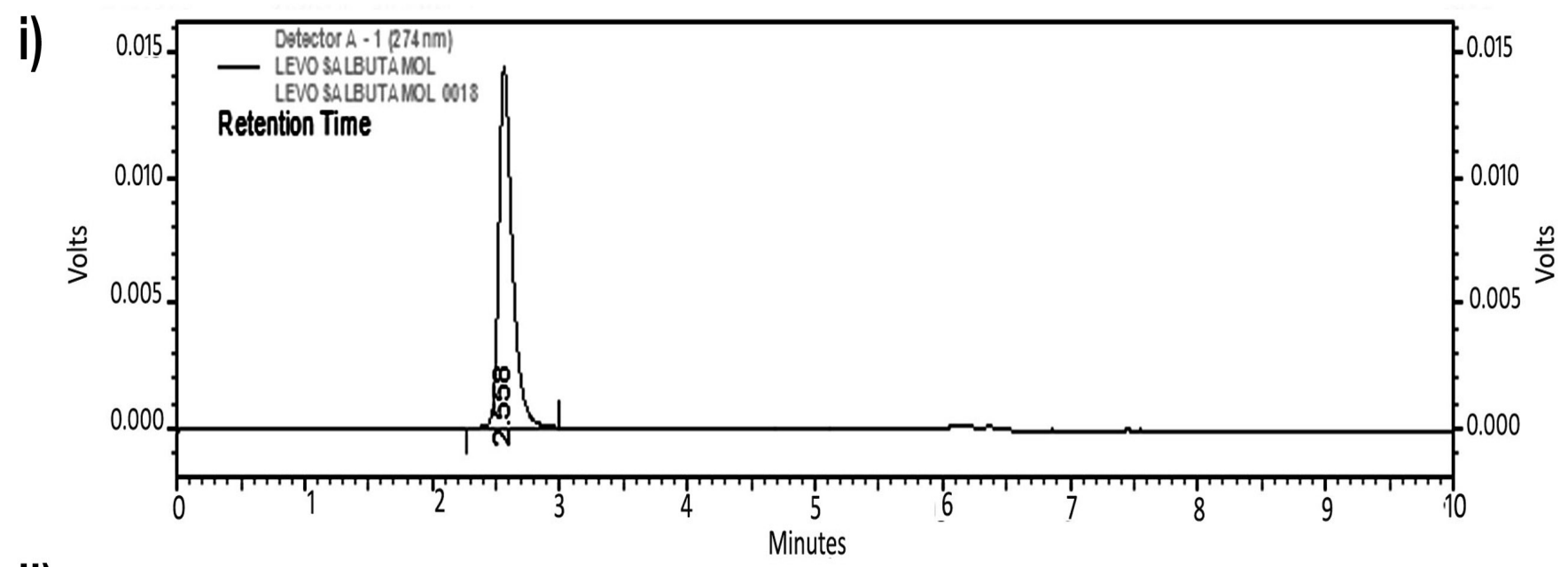

ii)

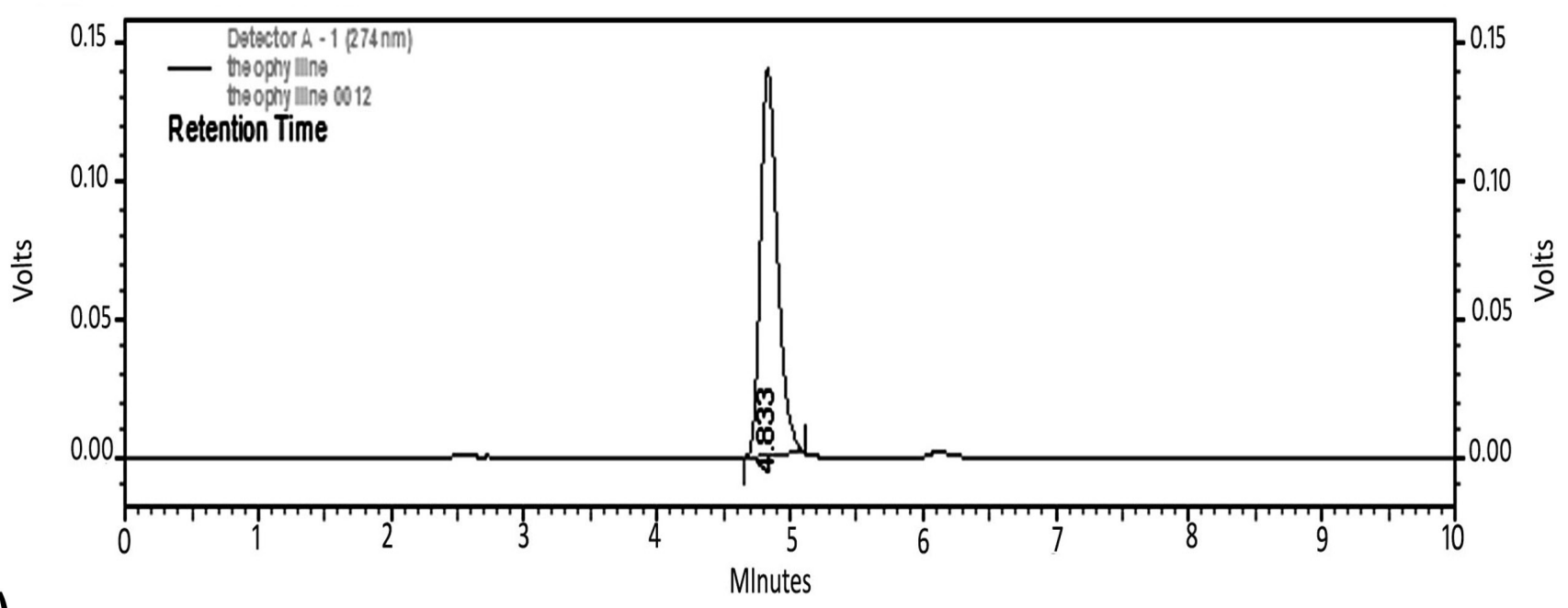

iii)

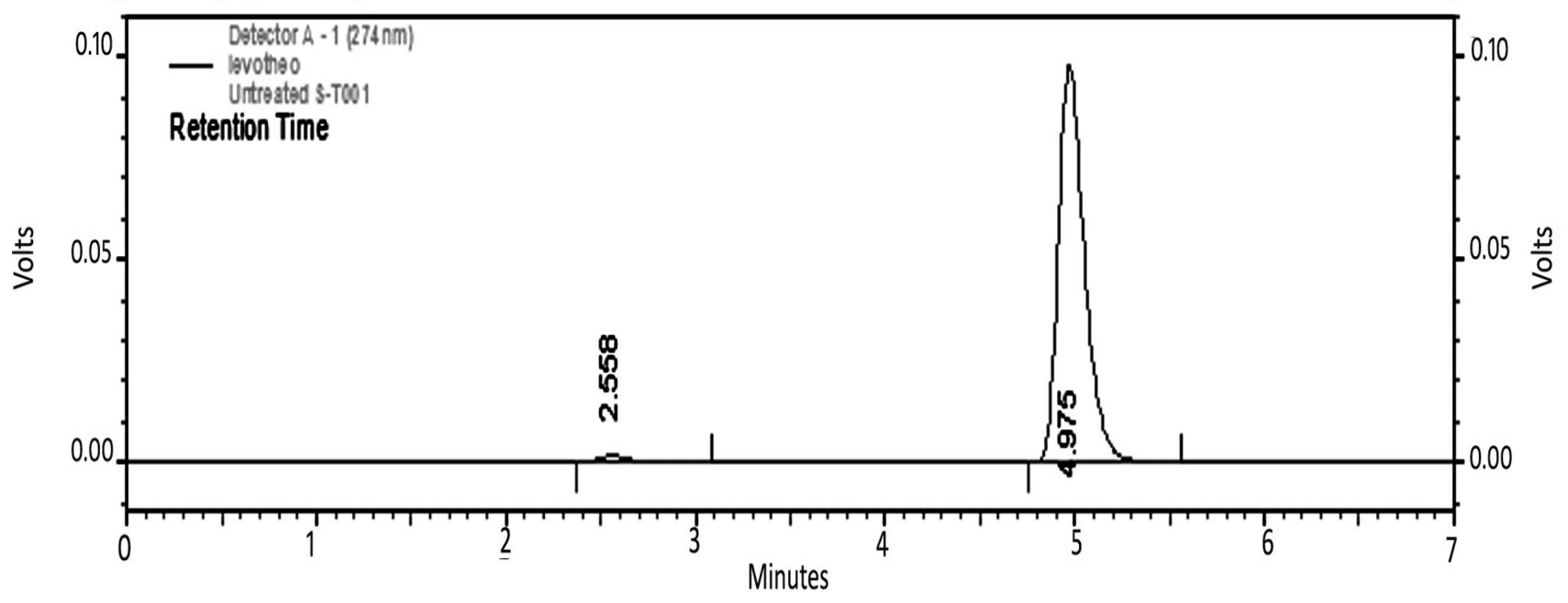

FIGURE 3A - Representative chromatograms of untreated drugs. Each chromatogram represents (i) levosalbutamol sulfate ( $\left.1 \mu \mathrm{g} \cdot \mathrm{mL}^{-1}\right)$, (ii) theophylline $\left(10 \mu \mathrm{g} \cdot \mathrm{mL}^{-1}\right)$, (iii) dosage form having levosalbutamol sulfate $\left(1 \mu \mathrm{g} \cdot \mathrm{mL}^{-1}\right)$ and theophylline $\left(10 \mu \mathrm{g} \cdot \mathrm{mL}^{-1}\right)$. 
i)

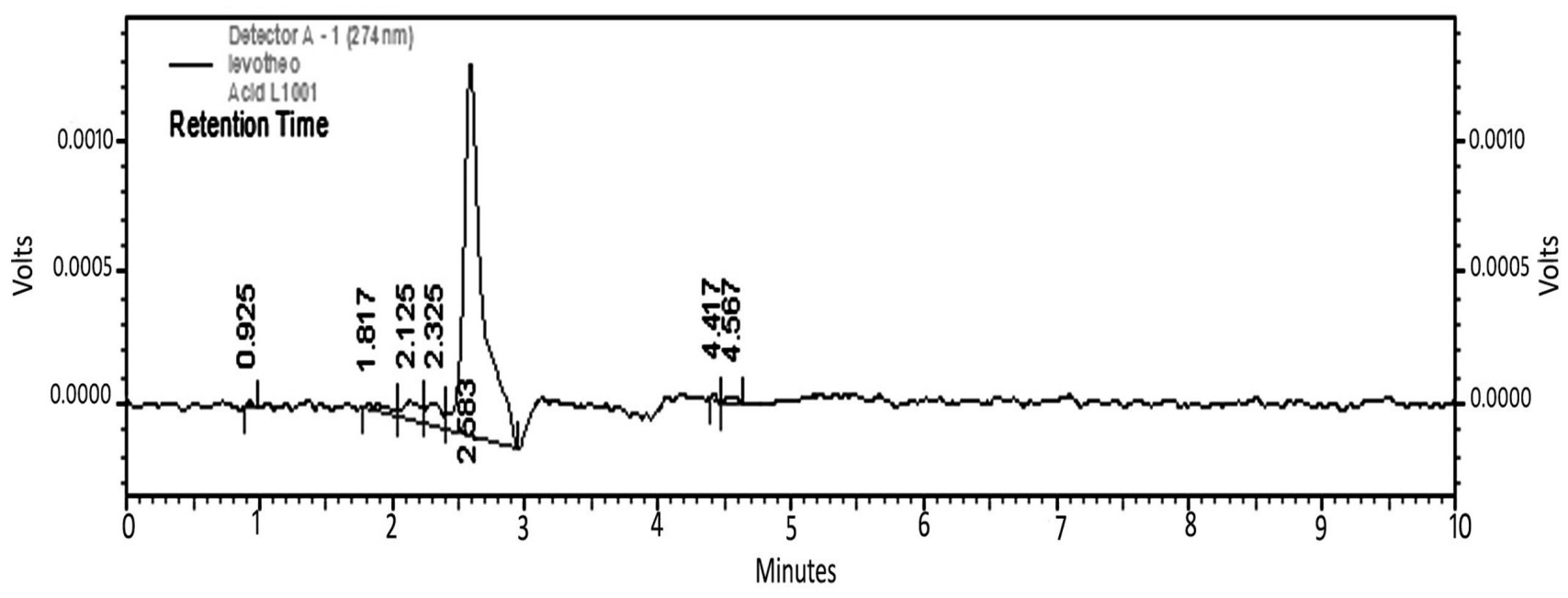

ii)

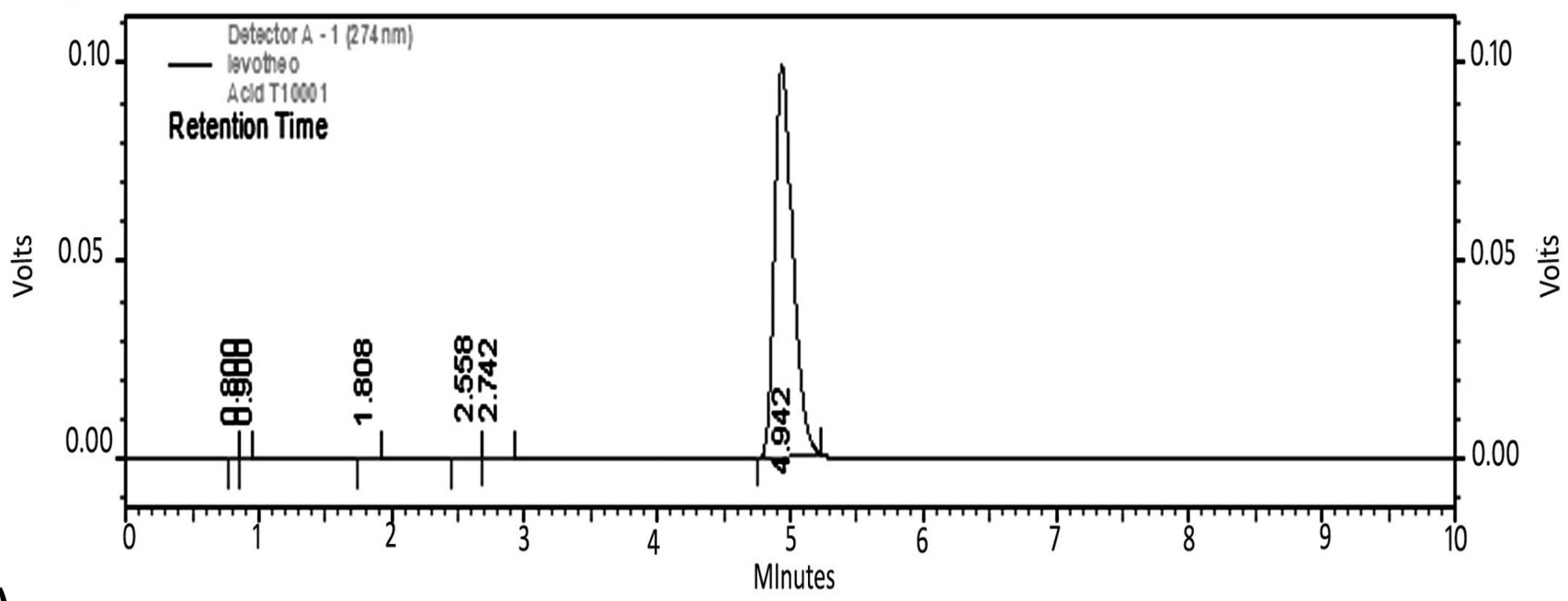

iii)

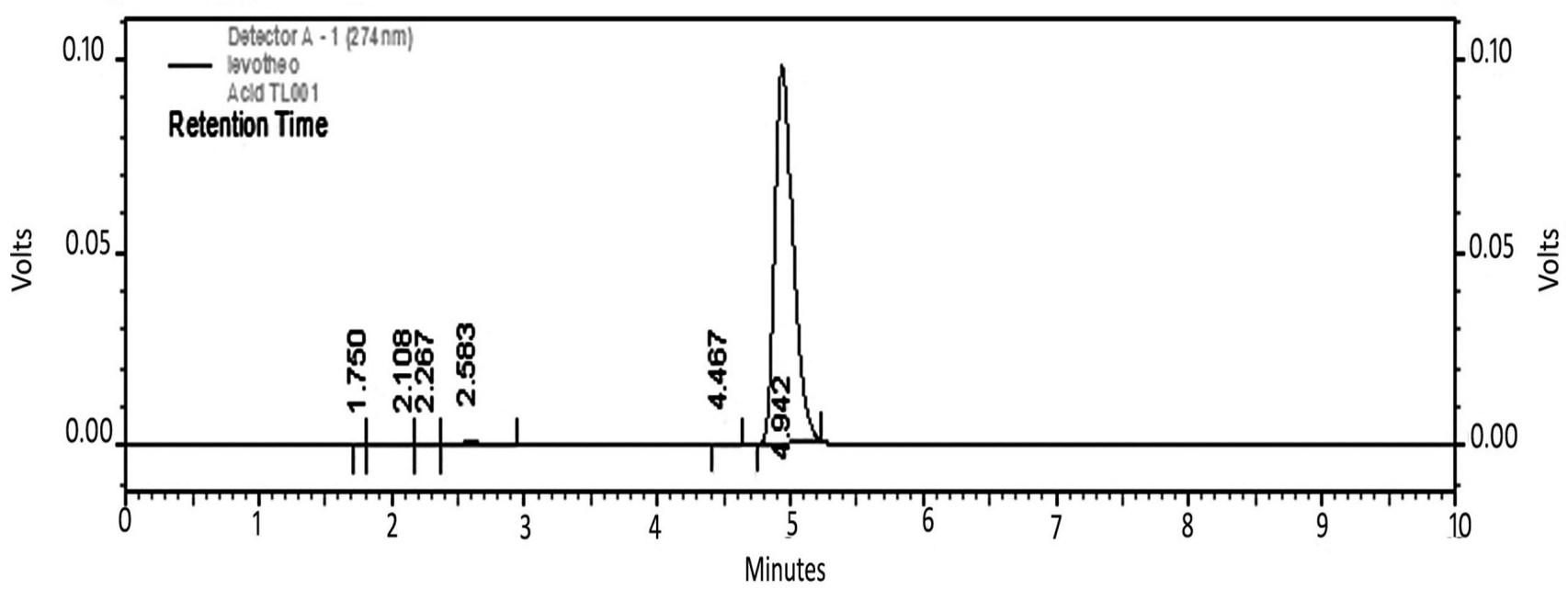

FIGURE 3B - Representative chromatograms of acid degraded drugs. Each chromatogram represents (i) levosalbutamol sulfate ( $\left.1 \mu \mathrm{g} \cdot \mathrm{mL}^{-1}\right)$, (ii) theophylline $\left(10 \mu \mathrm{g} \cdot \mathrm{mL}^{-1}\right)$, (iii) dosage form having levosalbutamol sulfate $\left(1 \mu \mathrm{g} \cdot \mathrm{mL}^{-1}\right)$ and theophylline $\left(10 \mu \mathrm{g} \cdot \mathrm{mL}^{-1}\right)$. 
i)

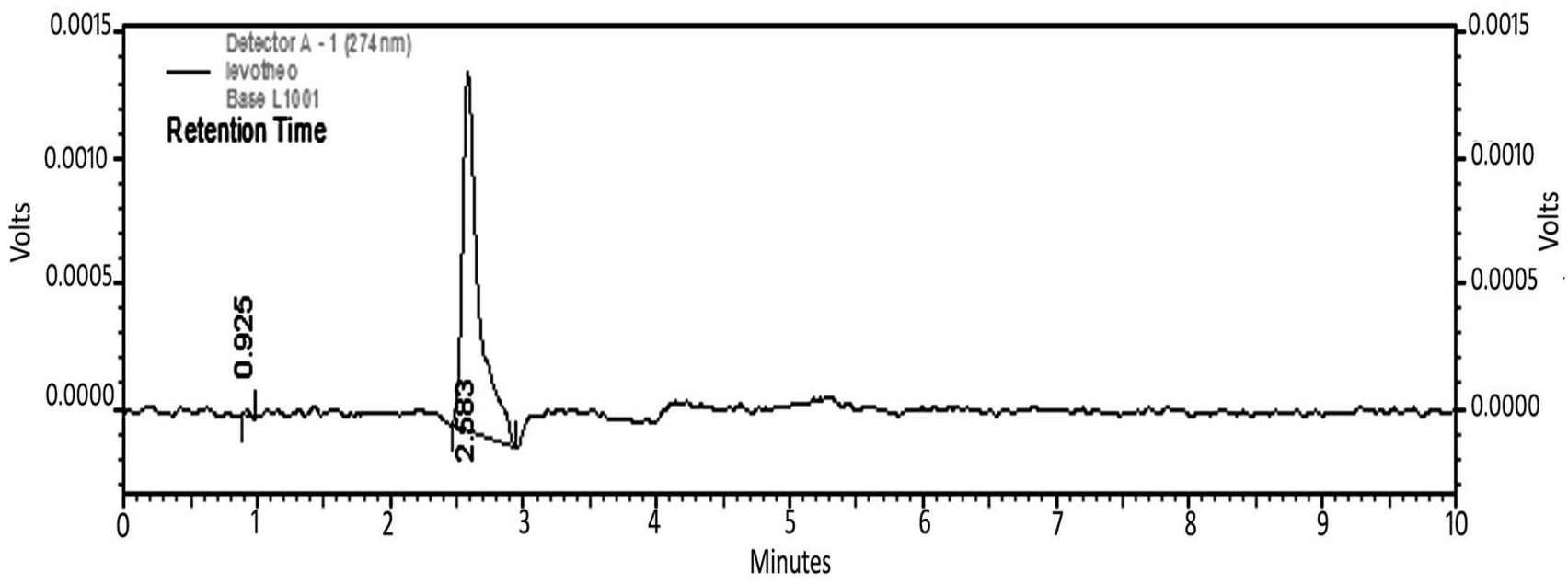

ii)

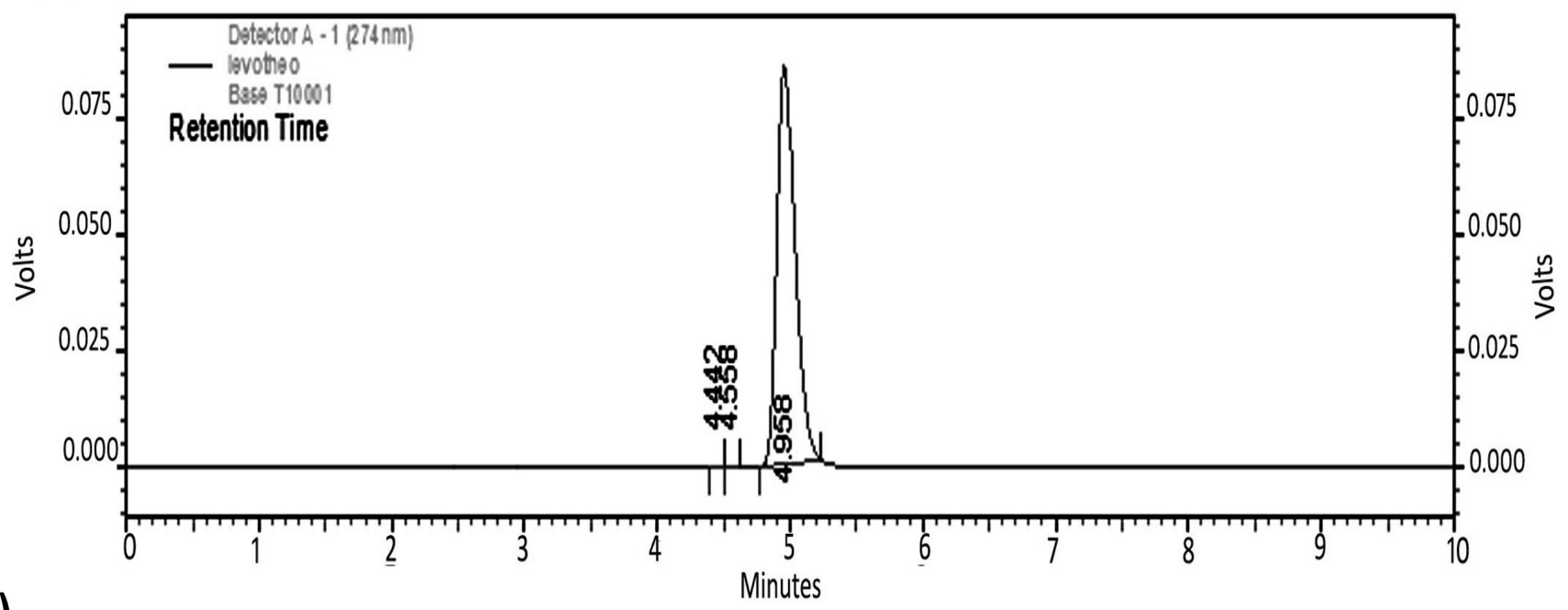

iii)

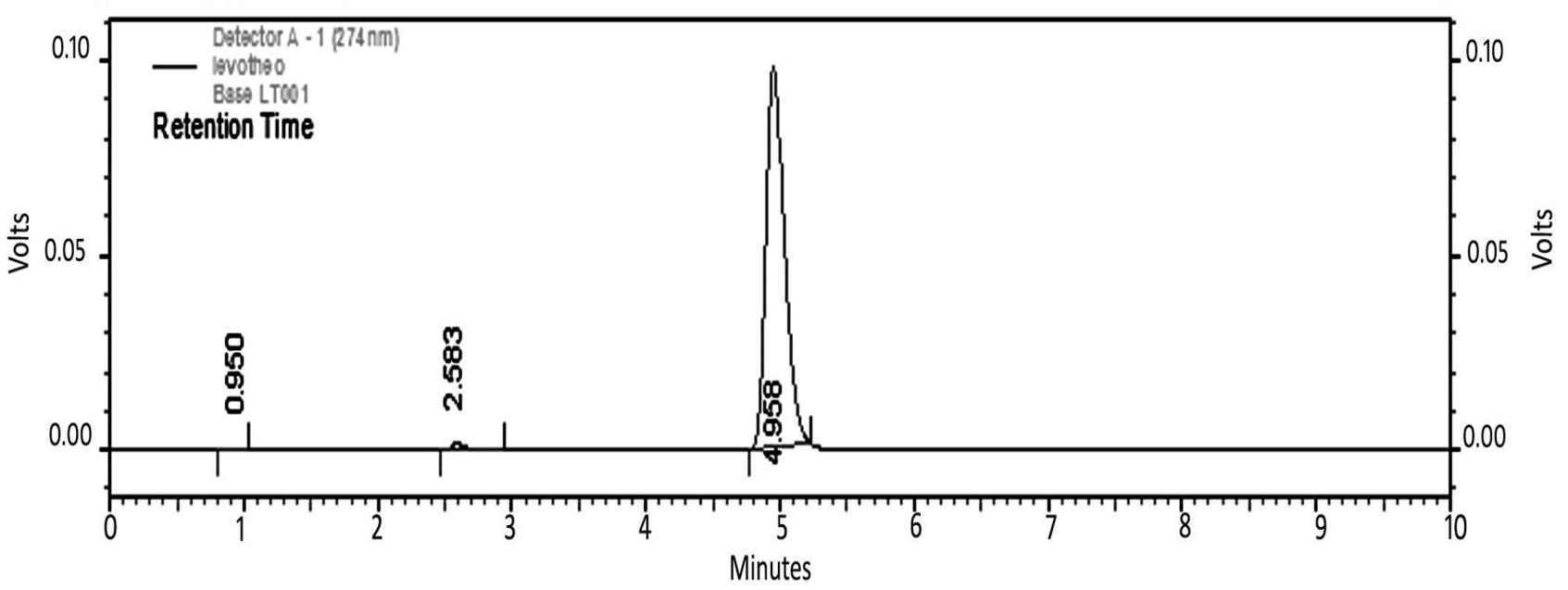

FIGURE 3C - Representative chromatograms of alkali degraded drugs. Each chromatogram represents (i) levosalbutamol sulfate ( $\left.1 \mu \mathrm{g} \cdot \mathrm{mL}^{-1}\right)$, (ii) theophylline $\left(10 \mu \mathrm{g} \cdot \mathrm{mL}^{-1}\right)$, (iii) dosage form having levosalbutamol sulfate $\left(1 \mu \mathrm{g} \cdot \mathrm{mL}^{-1}\right)$ and theophylline $\left(10 \mu \mathrm{g} \cdot \mathrm{mL}^{-1}\right)$. 


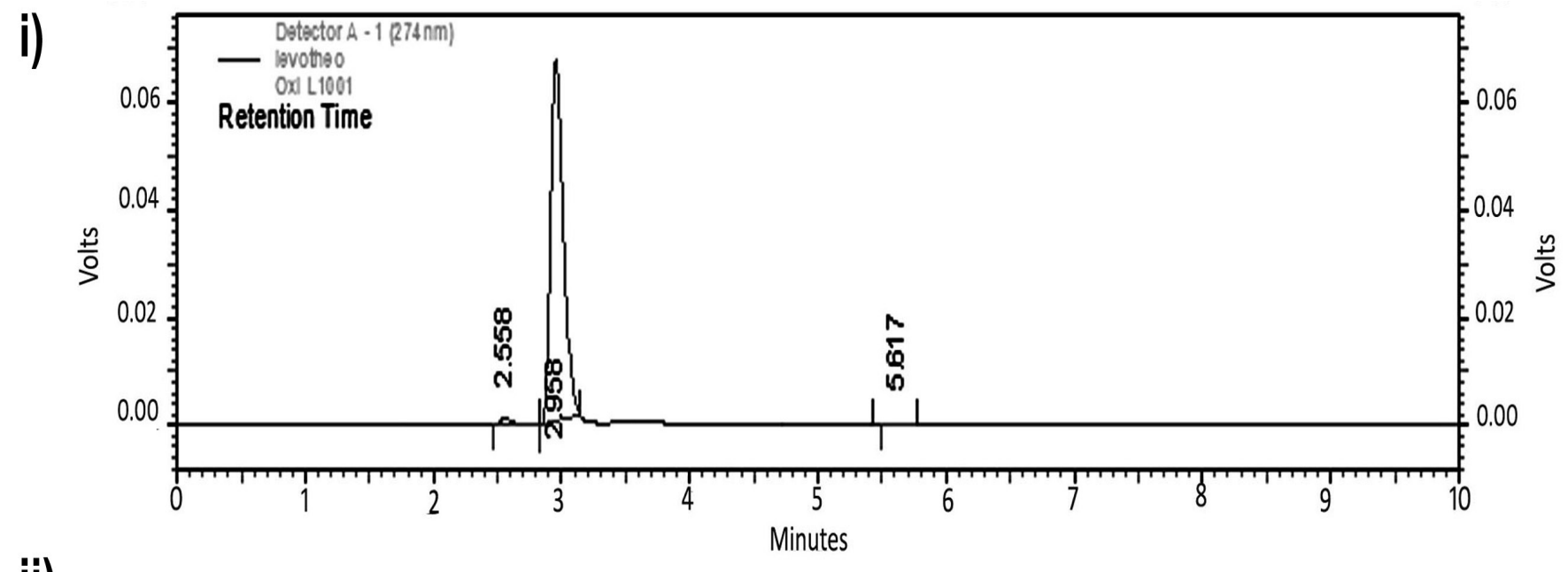

ii)

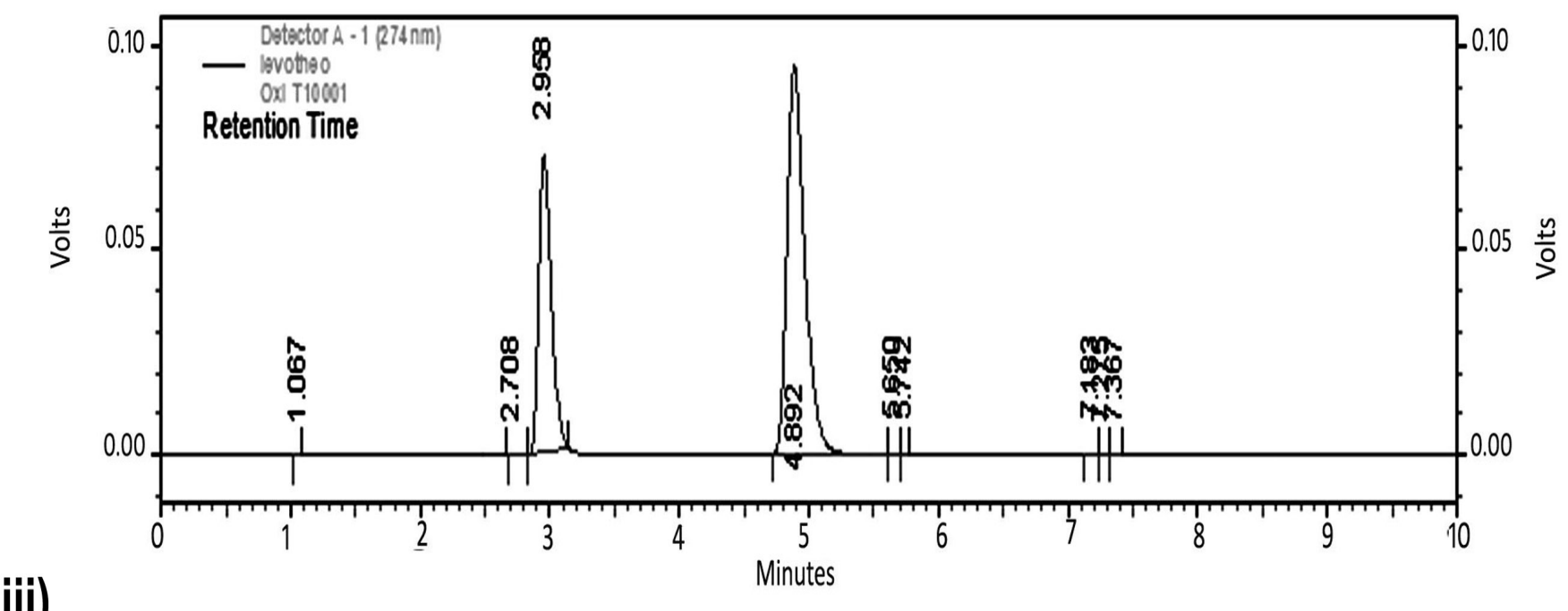

iii)

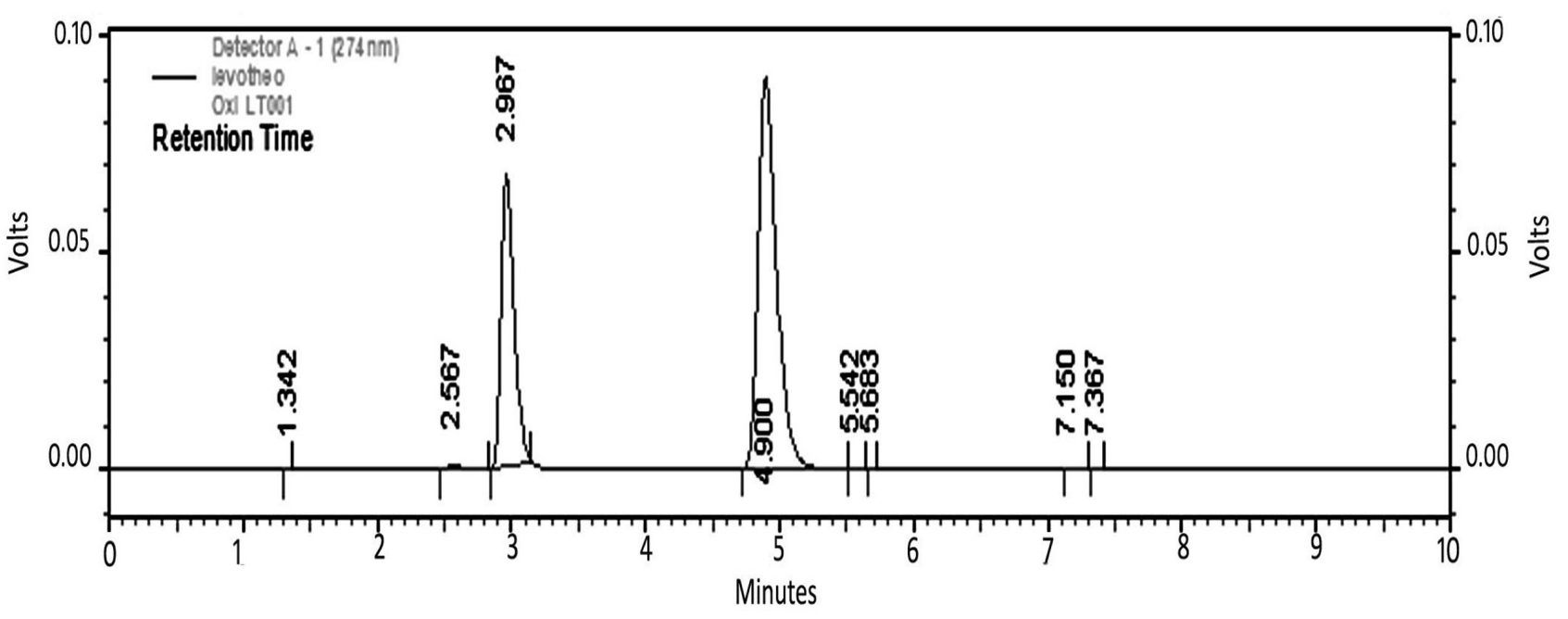

FIGURE 3D - Representative chromatograms of oxidation degraded drugs. Each chromatogram represents (i) levosalbutamol sulfate $\left(1 \mu \mathrm{g} \cdot \mathrm{mL}^{-1}\right)$, (ii) theophylline $\left(10 \mu \mathrm{g} \cdot \mathrm{mL}^{-1}\right)$, (iii) dosage form having levosalbutamol sulfate $\left(1 \mu \mathrm{g} \cdot \mathrm{mL}^{-1}\right)$ and theophylline $\left(10 \mu \mathrm{g} \cdot \mathrm{mL}^{-1}\right)$. 


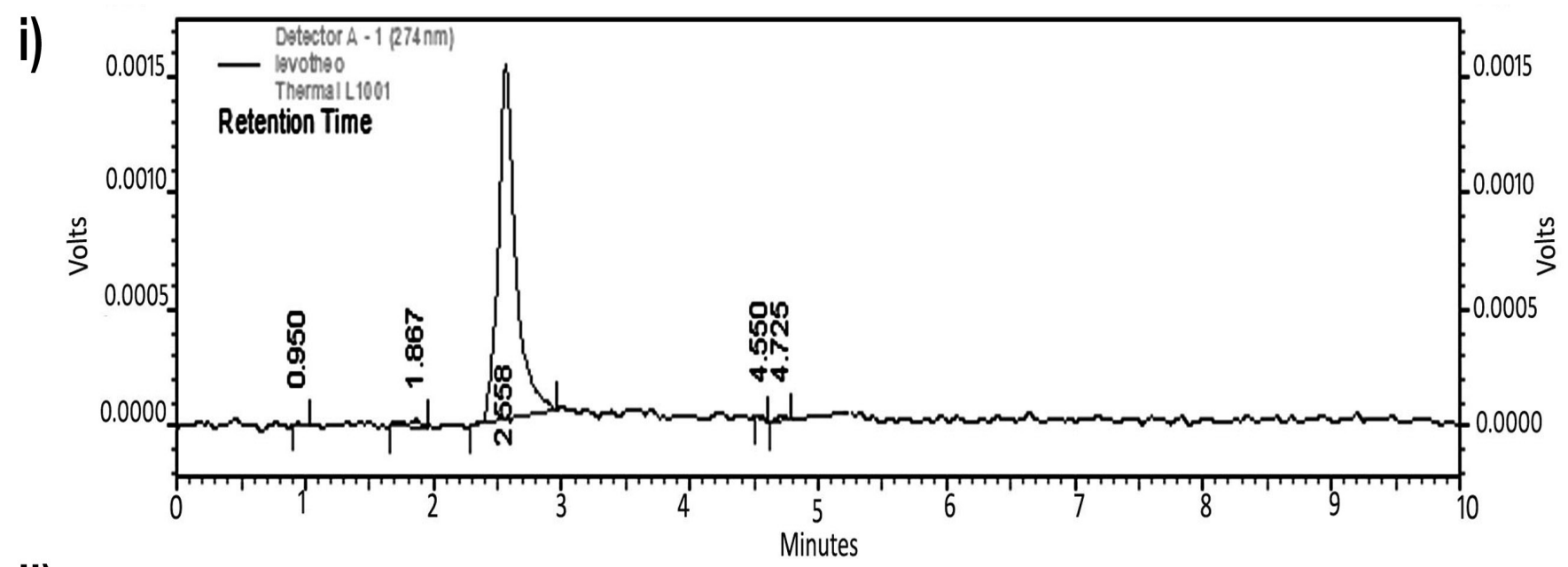

ii)
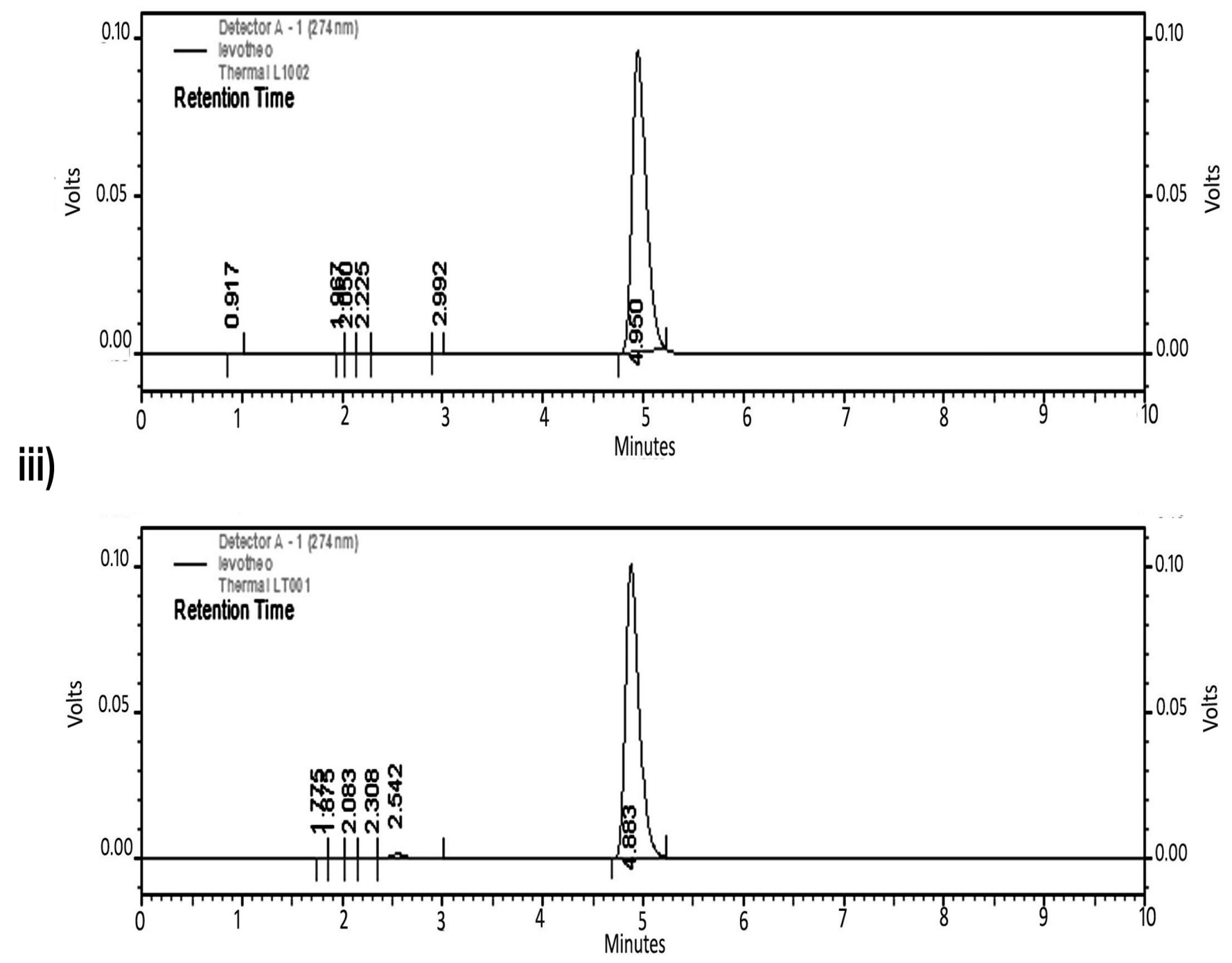

FIGURE 3E - Representative chromatograms of thermally degraded drugs. Each chromatogram represents (i) levosalbutamol sulfate $\left(1 \mu \mathrm{g} \cdot \mathrm{mL}^{-1}\right)$, (ii) theophylline $\left(10 \mu \mathrm{g} \cdot \mathrm{mL}^{-1}\right)$, (iii) dosage form having levosalbutamol sulfate $\left(1 \mu \mathrm{g} \cdot \mathrm{mL}^{-1}\right)$ and theophylline $\left(10 \mu \mathrm{g} \cdot \mathrm{mL}^{-1}\right)$. 


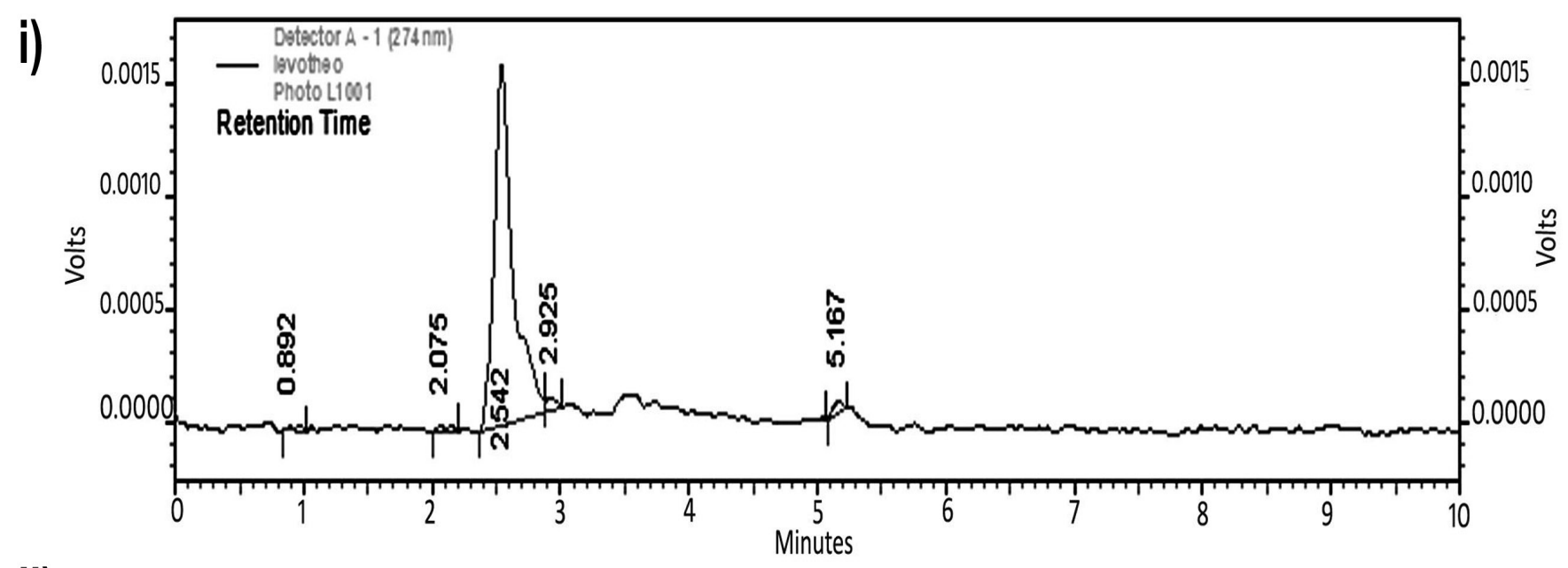

ii)

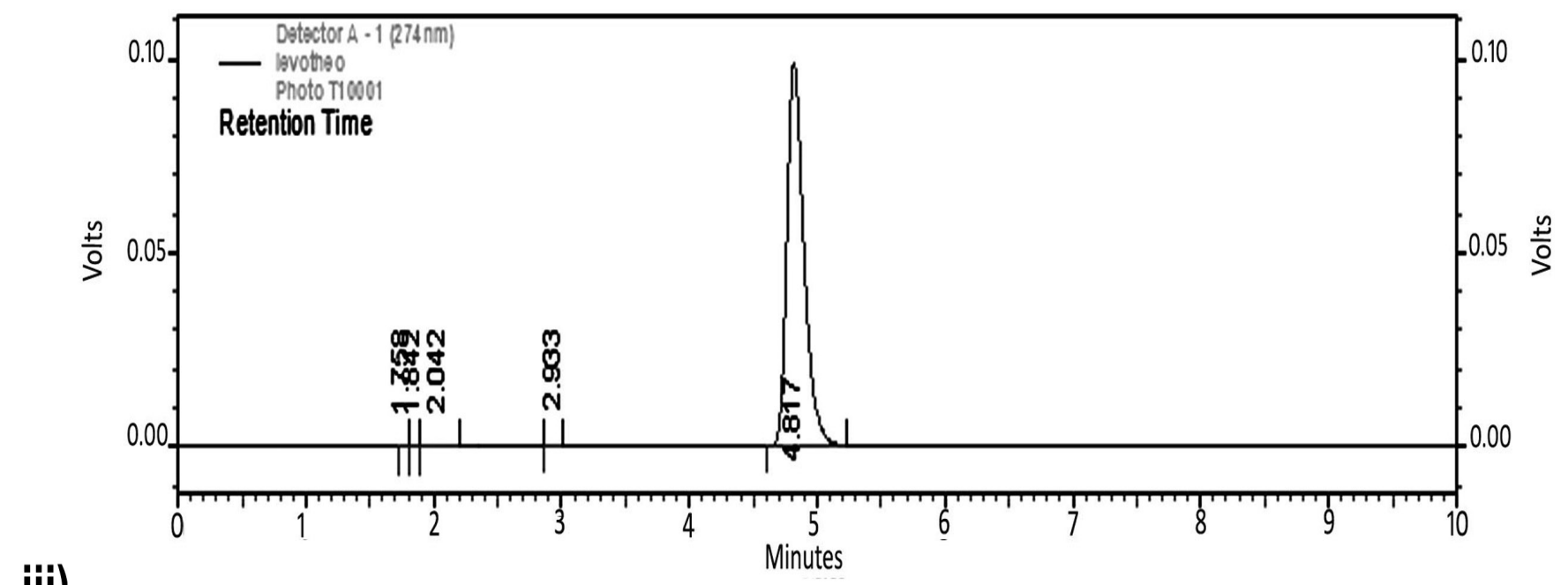

iii)

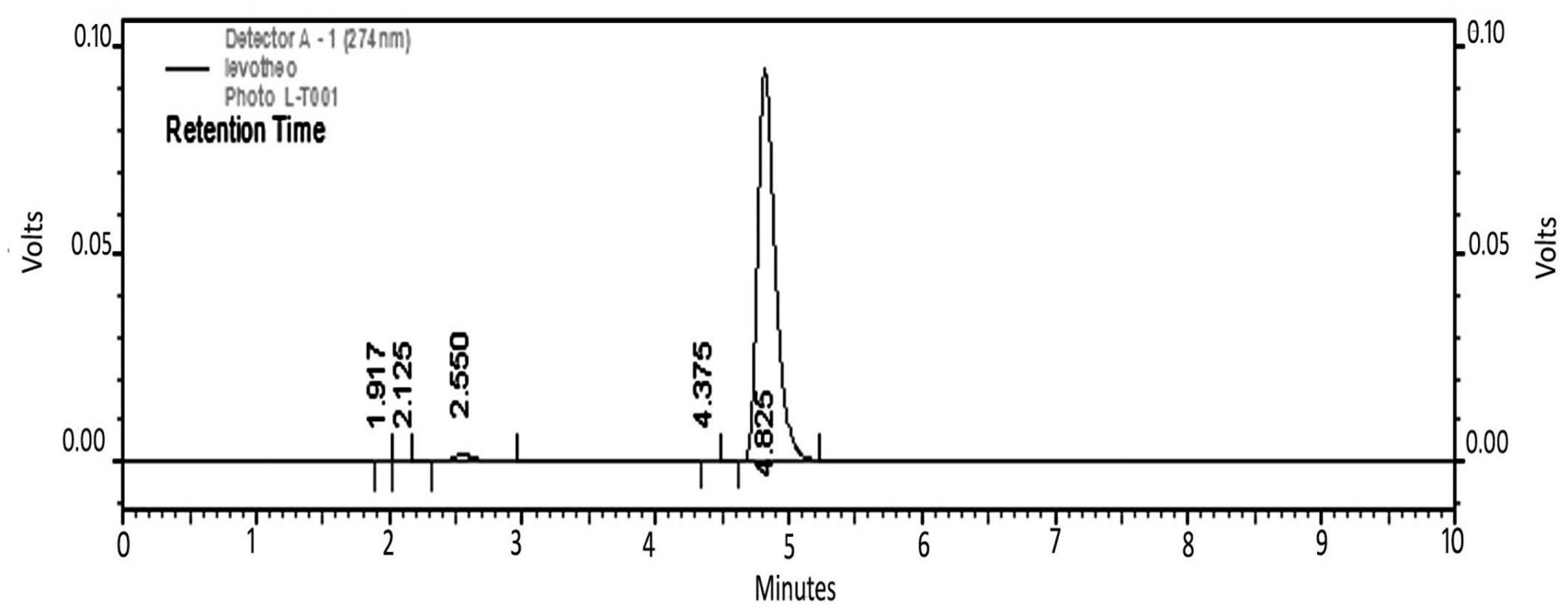

FIGURE 3F - Representative chromatograms of photolysed drugs. Each chromatogram represents (i) levosalbutamol sulfate ( $\left.1 \mu \mathrm{g} \cdot \mathrm{mL}^{-1}\right)$, (ii) theophylline $\left(10 \mu \mathrm{g} \cdot \mathrm{mL}^{-1}\right)$, (iii) dosage form having levosalbutamol sulfate $\left(1 \mu \mathrm{g} \cdot \mathrm{mL}^{-1}\right)$ and theophylline $\left(10 \mu \mathrm{g} \cdot \mathrm{mL}^{-1}\right)$. 


\section{ACKNOWLEDGEMENTS}

The authors are thankful to Cipla Ltd., India and Glenmark Pharmaceuticals Ltd., India for providing the standard drugs of levosalbutamol sulfate and theophylline, respectively, and M/S Roland Institute of Pharmaceutical Sciences, Berhampur-10, Odisha, India for providing the research facilities.

\section{REFERENCES}

ABUIRJEIE, M.A.; EL-DIN, M.S.; MAHMOUD, I.I. Determination of theobromine, theophylline and caffeine in various food products using derivative UVSpectrophotometric techniques and high performance liquid chromatography. J. Liq. Chromatogr., v.15, n.1, p.101-125, 1992.

ABDEL-GHANI, N.T.; RIZK, M.S.; EL-NASHAR, R.M. Potentiometric flow injection determination of salbutamol. Anal. Lett., v.35, n.1, p.39-52, 2002.

ABDEL-HAMID, M.E.; PHILLIPS, O.A. LC-MS/MS determination of carbamazepine and theophylline in human serum. J. Liq. Chromatogr. Related Technol., v.26, n.12, p.1937-1957, 2003.

BABU, A.R.S.; THIPPESWAMY, B.; VINOD, A.B.; RAMAKISHORE, E.G.; ANAND, S.; SENTHIL, D. Determination of theophylline in rabbit plasma by triple quadrupole LC/MS. Pharm. Methods, v.2, n.4, p.211-217, 2011.

BASAVAIAH, K.; SOMASHEKAR, B.C.; RAMAKRISHNA, V. Rapid titrimetric and spectrophotometric methods for salbutamol sulphate in pharmaceuticals using N-bromosuccinimide. Acta Pharm., v.57, n.1, p.87-98, 2007.

BASAVAIAH, K.; PRAMEELA, H.C. Spectrophotometric determination of salbutamol sulfate(SBS) and pyrantel pamoate(PRP) in bulk drugs and pharmaceuticals. Chem. Anal., v.48, n.2, p.327, 2003.

BASAVAIAH, K.; SOMASHEKAR, B.C.; RAMAKRISHNA, V. Titrimetric and spectrophotometric determination of salbutamol sulphate in pharmaceuticals using chloramines- $T$ and two dyes. Anal. Chem. Ind. J., v.2, n.5-6, p.179-186, 2006.
BERGER, W.W. Levalbuterol; pharmacologic properties and use in the treatment of pediatric and adult asthma. Ann. Allergy Asthma In., v.90, n.6, p.583-592, 2003.

BERMEJO, A.; LOPEZ-RIVADULLA, M.; FERNANDEZ, P.; CONCHEIRO, L. Application of derivative spectroscopy to the determination of plasma theophylline in the presence of phenobarbital. J. Anal. Toxicol., v.9, n.2, p.76-80, 1985.

BERNAL, J.L.; DEL NOZAL, M.J.; VELASCO, H.; TORIBIO, L. HPLC versus SFC for the determination of salbutamol sulphate and its impurities in pharmaceuticals. J. Liq. Chromatogr. Related Technol., v.19, n.10, p.1579-1589, 1996.

BOBERIC-BOROJEVIC, D.; RADULOVIC, D.; IVANOVIC, D.; RISTIC, P. Simultaneous assay of ephedrine hydrochlor ide, theophylline,papaverine hydrochloride and hydroxyzine hydrochloride in tablets using rp-lc. J. Pharm. Biomed. Anal., v.21, n.1, p.15-22, 1999.

BOULTON, D.W.; FAWCETT, J.P. Determination of salbutamol enantiomers in human plasma and urine by chiral highperformance liquid chromatography. J. Chromatogr. B., v.672, n.1, p.103-109, 1995.

CARTER, P.; WALLACE, J.E.; BLUM, K. Improved ultraviolet spectrophotometry of serum theophylline. Clin. Chem., v.24, n.2, p.360-361, 1978

CHITLANGE, S.S.; CHATURVEDI, K.K.; WANHEDE, S.B. Development and validation of spectrophotometric and HPLC method for simultaneous estimation of salbutamol sulphate and prednisolone in tablet dosage form. J. Anal. Bioanal. Techniques., v.2, n.1, p.117, 2011.

CHRZANOWSKI, F.A.; NIEBERGALL, P.J.; NIKELLY, J.G.; SUGITA, E.T.; SCHNAARE, R.L. Gas chromatographic analysis of theophylline in human serum. Biochem. Med., v.11, n.1, p.26-31, 1974

CULZONI, M.J.; DE ZAN, M.M.; ROBLES, J.C.; MANTOVANI, V.E.; GOICOECHEA, H.C. Chemometrics -assisted UV-spectroscopic strategies for the determination of theophylline in syrups. J. Pharm. Biomed. Anal., v.39, n.5, p.1068-1074, 2005.

ERRAM, S.V.; FANSKA, C.B.; ASIF, M. Determination of albuterol sulfate and its related substances in albuterol sulfate inhalation solution, $0.5 \%$ by RP-LC. J. Pharm. Biomed. Anal., v.40, n.4, p.864-874, 2006. 
FELLENBERG, A.J.; POLLARD, A.C. A rapid ultraviolet spectrophotometric procedure for the microdetermination of theophylline(1,3-dimethylxanthine) in plasma or serum. Clin. Chim. Acta, v.92, n.2, p.267-272, 1979.

GEETA, N.; BAGGI, T.R. An improved spectrophotometric method for the determination of salbutamol sulfate with 3-methylbenzthiazolinone-2-hydrazone. Microchem. J., v.39, n.2, p.137-144, 1989.

GHEMUD, A.S.; SANTHAKUMARI, B.; PHARNE, A.B.; JADHAV, M.M.; JAIN, K.S.; KULKARNI, M.J. Bioanalytical method development and validation of levalbuterol a $\beta_{2}$-adrenergic agonist by rp-hplc method. Int. J. Pharm. Pharm. Sci., v.4, suppl.1, p.249-253, 2012.

GREENBERG, M.S.; MAYER, W.J .High performance liquid chromatographic determination of theophylline and its derivatives with electrochemical detection. J. Chromatogr. A., v.169, p.321-327, 1979.

HABIB, I.H.I.; HASSOUNA, M.E.M.; ZAKI, G.A. Simultaneous spectrophotometric determination of salbutamol and bromhexine in tablets. Farmaco, v.60, n.3, p.249-254, 2005.

HALABI, A.; FERRAYOLI, C.; PALACIO, M.; DABBENE, V.; PALACIOS, S. Validation of a chiral HPLC assay for (R) - salbutamol sulfate. J. Pharm. Biomed. Anal., v.34, n.45, p.45-51, 2004.

HOHNADEL, D.C.; GROVE, T.H.; ALONZO, P. A micro method for the ultraviolet spectrophotometric determination of theophylline. J. Anal. Toxicol., v.2, n.4, p.141-145, 1978.

\section{ICH HARMONISED TRIPARTITE GUIDELINE. Validation} of analytical procedures: text and methodology Q2(R1). Available at: < http://www.ich.org/fileadmin/Public_Web_ Site/ICH_Products/Guidelines/Quality/Q2_R1/Step4/ Q2_R1_Guideline.pdf>. Accessed on: 10 Jan 2012.

JAIN, D.K.; PATEL, P.; KUSHWAHA, A.; RAGHUWANSHI, R.S.; JAIN, N. Simultaneous determination of salbutamol sulphate and doxophylline in tablets by reverse phase liquid chromatography. Pharmacia Lettre., v.3, n.4, p.56-62, 2011.

JATLOW, P. Ultraviolet spectrophotometry of theophylline in plasma in the presence of barbiturates. Clin. Chem., v.21, n.10, p.1518-1520, 1975.
JOYCE, K.B.; JONES, A.E.; SCOTT, R.J.; BIDDLECOMBE, R.A.; PLEASANCE, S. Determination of the enantiomers of salbutamol and its 4-O-sulfate metabolites in biological matrices by chiral liquid chromatography tandem mass spectrometry. Rapid Commun. Mass Spectrom., v.12, n.23, p.1899-1910, 1998.

KANAZAWA, H.; ATSUMI, R.; MATSUSHIMA, Y.; KIZU, $Z$. Determination of theophylline and its metabolites in biological samples by liquid chromatography-mass spectrometry. J. Chromatogr. A., v.870, n.1-2, p.87-96, 2000 .

KASAWAR, G.B.; FAROOQUI, M. Development and validation of a stability indicating RP-HPLC method for the simultaneous determination of related substances of albuterol sulfate and ipratropium bromide in nasal solution. J. Pharm. Biomed. Anal., v.52, n.1, p.19-29, 2010.

KUMAR, V.; SHARMA, A.; ARORA, S.; DHILLON, V. Use of simple spectrophotometric method for estimation of theophylline (TH) in saliva and urine of healthy human volunteer. Int. J. Pharm. Bio Sci., v.2, n.3, p.36-41, 2011.

KOUNTOURELLIS, J.E.; MARKOPOULOU, C.; GEORGAKOPOULOS, P.P. Separation and simultaneous determination of bamipine and salbutamol in dosage forms by high-performance liquid chromatography. $J$. Chromatogr. A., v.502, n.1, p.189-192, 1990.

LAUFF, J.J. Ion-pair high-performance liquid chromatographic procedure for the quantitative analysis of theophylline in serum samples. J. Chromatogr., v.417, n.1, p.99-109, 1987.

MAITHANI, M.; SINGH, R. Development and validation of a stability-indicating HPLC method for the simultaneous determination of salbutamol sulfate and theophylline in pharmaceutical dosage forms. J. Anal. Bioanal. Techniques., v.2, n.1, p.1-5, 2011.

MALLU, U.R.; BOBBARALA, V.; PENUMAJJI, S. Analysis of cough and analgesic range of pharmaceutical active ingredients using rp-hplc method. Int. J. Pharm. Bio. Sci., v.2, n.3, p.439-452, 2011.

MARTIS, E.; GANGRADE, D.M. Reverse phase isocratic HPLC method for simultaneous estimation of salbutamol sulphate and beclomethasone dipropionate in rotacaps formulation dosage forms. Int. J. Pharm. Pharm. Sci., v.3, n.1, p.64-67, 2011. 
MISHRA, A.K.; KUMAR, M.; MISHRA, A.; VERMA, A; CHATTOPAHYAY, P. Validated UV spectroscopic method for estimation of salbutamol from tablet formulations. Arch. Appl. Sci. Res., v.2, n.3, p.207-211, 2010.

MONCRIEFF, J. Determination of theophylline in serum and saliva in the presence of caffeine and its metabolites. $J$. Chromatogr. B Biomed. Sci. Appl., v.568, n.1, p.177-185, 1991.

MURTAZA, G.; AHMAD, M.; MADNI, M.A.; ASGHAR, M.W. A new reverse phase hplc method with fluorescent detection for the determination of salbutamol sulfate in human plasma. Bull. Chem. Soc. Ethiop., v.23, n.1, p.1-8, 2009.

PAI, P.N.S.; RAO, G.K.; MURTHY, M.S.; AGARWAL, A.; PURANIK, S. Simultaneous determination of salbutamol sulphate and bromhexine hydrochloride in tablets by reverse phase liquid chromatography. Ind. J. Pharm. Sci., v.71, n.1, p.53-55, 2009.

PANDYA, H.N.; BERAWALA, H.H.; KHATRI, D.M.; MEHTA, P.J. Spectrofluorimetric estimation of salbutamol sulphate in different dosage forms by formation of inclusion complex with $\beta$-cyclodextrin. Pharm. Methods, v.1, n.1, p.49-53, 2010.

PAPADOYANNIS, I.N.; SAMANIDOU, V.F.; TSOUKALI, H.; EPIVATIANOU, F. Comparison of a rp-hplc method with the therapeutic drug monitoring system TDx for the determination of theophylline in blood serum. Anal. Lett., v.26, n.10, p.2127-2142, 1993.

PARIMOO, P.; UMAPATHI, P.; ILANGO, K. Simultaneous quantitative determination of salbutamol sulfate and bromhexine hydrochloride in drug preparations by difference spectrophotometry. Int. J. Pharm., v.100, n.1-3, p.227-231,1993.

PERSSON, C.G.A. Overview of effects of theophylline. $J$. Allergy Clin. Immunol., v.78, n.4, p.780-787, 1986.

PLAVSIC, F. A simple UV spectrophotometric method for theophylline serum level determination. Clin. Chim. Acta., v.88, n.3, p.551-558, 1978.

PRASANNA, B.L.; SHETTY, A.S.K.; NADH, T.P.; GOPINATH, B.; AHMED, M. Simultaneous estimation of levosalbutamol sulphate and beclomethasone dipropionate in combined rotacap dosage form by rp-hplc method. Int. J. Biol. Pharm. Res., v.3, n.3, p.320-326, 2012.
PRASANNA, B.L.; SHETTY,A.S.K.; NADH, T.P.; GOPINATH, B.; AHMED, M. Development of new spectrophotometric methods for the simultaneous estimation of levosalbutamol sulfate and beclomethasone dipropionate in bulk drug and pharmaceutical formulations(rotacap). Int. J. PharmTech Res., v.4, n.2, p.791-798, 2012.

RATHORE, Y.K.S.; MURUGESAN, N.; MATHUR, S.C.; KUMAR, Y; SETHI, P.D. Simultaneous spectrophotometric determination of salbutamol sulphate and bromhexine hydrochloride in tablets. Ind. J. Pharm. Sci., v.55, n.5, p.206-208, 1993.

SCHWERTNER, H.A. Analysis for underivatized theophylline by gas-chromatography on a silicone stationary phase SP2510-DA. Clin. Chem., v.25, n.2, p.212-214, 1979.

SHAH, V.P.; RIEGELMAN, S. GLC determination of theophylline in biological fluids. J. Pharm. Sci., v.63, n.8, p.1283-1285, 1974 .

SHIDHAYE, S.; MALKE, S.; KADAM, V. Validated stability indicating hplc method for estimation of theophylline from a novel microsphere formulation. Asian J. Pharm., v.3, n.1, p.13-17, 2009

SONG, J.; UNPARK, K.; PARK, H.D.; YOON, Y.; KIM, J.Q. High throughput liquid chromatography-tandem mass spectrometry assay for plasma theophylline and its metabolites. Clin. Chem., v.50, n.11, p.2176-2179, 2004.

T H U L A S A M A, P.; K I S H R E KUMAR, R.; VENKATESWARULU, P. Development and validation of new spectrophotometric methods for the estimation of levosalbutamol in tablet dosage forms. Anal. Chem. Ind. J., v.8, n.4, p.222-231, 2009.

VASILIADES, J.; TURNER, T. A modified spectrophotometric method for the determination of theophylline in serum in the presence of barbiturates. Clin. Chim. Acta, v.69, n.3, p.491-495, 1976.

WU, S.T.; XING, J.; APEDO, A.; WANG-IVERSON, D.B.; OLAH, T.V.; TYMIAK, A.A.; ZHAO, N. High-throughput chiral analysis of albuterol enanantiomers in dog plasma using on-line sample extraction/polar organic mode chiral liquid chromatography with tandem mass spectrometric detection. Rapid Commun. Mass Spectrom., v.18, n.21, p.2531-2536, 2004. 
WU, J.; DING, C.; GE, Q.; LI, Z.; ZHOU, Z.; ZHI, Z. Simultaneous determination of ipatropium and salbutamol in rat plasma by LC-MS/MS and its application to a pharmacokinetic study. J. Chromatogr. B Analyt. Technol. Biomed. Life Sci., v.879, n.30, p.3475-3483, 2011.
YEE, K.C.; JACOBSON, G.A.; WOOD-BAKER, R.; WALTERS, E.H. Albuterol enantiomer levels, lung function and QTc interval in patients with acute severe asthma and COPD in the emergency department. Int. J. Emergency Med., v.4, n.1, p.30, 2011.

Received for publication on 28 May 2012 Accepted for publication on 16 May 2013 